\title{
MUSYTAQ DALAM BAHASA ARAB; ANALISIS FILOSOFIS MENURUT M. SYAHRUR
}

\section{Chamzawi}

Pembantu Dekan Bidang Akademik

Fakultas Humaniora dan Budaya, Universitas Islam Negeri (UIN) Malang.

Jalan Gajayana No. 50 Telepon (0341) 570872, Faksimile (0341) 570872 Malang 65144.

\begin{abstract}
This paper discusses the base forms of Arabic words in Syahrur's perspective. Syahrur argues that the base forms of Arabic words result from fi'il amr (imperative form), not from fi'il madhi (past tense form) as what Ulama's Kufah stated, and also not from isim mashdar as what Ulama' Bashrah argued. Syahrur's opinion cannot be separated from his philosophy concerning the fact that Moslems have still left behind by the other religious communities.
\end{abstract}

\section{Key words}

Shahrur, Musytaq, The Base Form of Arabic

\section{Pendahuluan}

Dalam khazanah pemikiran kebahasaan Arab, telah muncul perdebatan seputar persoalan dari manakah asal mula sebuah kata. Dalam hal ini, kita telah mengetahui bahwa terdapat dua aliran. Pertama, Aliran Kufah yang dimotori ulama Kufah. Mereka menyatakan bahwa asal kata dalam bahasa Arab (musytaq) adalah fi'il madhi. Hal ini didasarkan pada argumentasi bahwa berawal dari fi'il ini, lalu semua kata muncul. Dari sisi tinjauan waktu, kata "madhi" (lampau) mengandung arti sesuatu yang telah terjadi, mendahului. Kedua, Aliran 
Bashrah. Mereka berpendapat bahwa yang tepat, asal kata (musytaq) adalah mashdar. Hal ini ditinjau dari makna kata "mashdar" sendiri sebagai inti kata. Dari sini, lalu muncul berbagai bentuk kata yang lain. Di samping itu, fi'il ini yang memiliki susunan paling sederhana atau fundamental (asasi).

Di penghujung akhir abad ke-20, dalam blantika pemikiran Islam telah muncul seorang pemikir kontemporer, yaitu Muhammad Syahrur. Pemikir ini telah menimbulkan gejolak dalam konstalasi pemikiran Islam melalui karyanya yang sangat terkenal "Al-Kitab wa Al-Qur'an: Qira'ah Mu'ashirah". Di antara kekhasan pemikirannya adlah tentang musytaq-nya kata dalam bahasa Arab. Tulisan ini hendak membahas perihal bagaimana pendapat Syahrur tentang musytaq kata dalam bahasa Arab yang dulu pernah menjadi perdebatan dalam tradisi pemikiran kebahasaan Islam. Tulisan ini juga akan menelusuri dasar pemikiran Syahrur sehingga ia mempunyai pendapat yang berbeda dari pendahulunya.

\section{Sekilas tentang M. Syahrur}

Damaskus bagi M. Syahrur nampaknya akan menjadi kota mati yang paling bersejarah dalam hidupnya. Hal ini setidaknya didasarkan pada beberapa alasan. Pertama, Damaskus adalah kota dimana ia dilahirkan pada tahun 1938 dan kemudian ia mulai menapaki jenjang pendidikan dasar dan menengah sebelum kemudian ia pergi ke Moskow untuk belajar ilmu tehnik (engineering). Dilanjutkan dua tahun kemudian (tahun 1968) ia meneruskan pendidikan master dan doktoralnya dalam bidang mekanika perminyakan (soil mechanics) dan tehnik bangunan (foundation engineering) di Irlandia, University College Dublin. Kedua, di kota ini pula, setelah kembali dari Irlandia tahun 1972, ia memulai kiprah intelektualnya sebagai seorang profesor tehnik (engineer) di Universitas Damaskus, Syiria, hingga sekarang. Syahrur meskipun seorang insinyur, namun berkat perhatiannya dalam pemikiran Islam yang dituangkannya dalam karya monumentalnya $\mathrm{Al}$ - 
Kitab wa Al-Qur'an: Qira'ah Mua;shirah, ia kemudian masuk ke jajaran intelektual muslim terkemuka (Kurzman, 1998;139).

Masterpiece Syahrur yang telah mencuatkan namanya dalam blantika pemikiran Islam kontemporer tersebut merupakan hasil perjalanan penjangnya sekitar 20 tahun. Secara gradual, perjalanan pemikiran keislamannya dibagi dalam 3 (tiga) fase. Pertama, tahun 19701980. Fase ini dimulai saat ia sedang studi di Dublin, Irlandia. Dia merasakan bahwasanya kajian keislamannya tidak menghasilkan sesuatu yang bermakna terutama saat ia mengkaji tentang masalah "AlDzikr" baik yang mencakup metodologi, istilah-istilah pokok, maupun pemahaman tentang risalah dan kenabian. Ia melihat bahwasanya kajian keislanannya itu terjebak dalam tradisi taqlid, pembahasannya hanya itu-itu saja dan mengekor pada pemikiran terdahulu. Demikian halnya dengan kajian tradisi kalam dan fiqh. Tradisi pemikiran Islam telah terjebak dalam tradisi pemikiran 'Asy'ariyah ataupun Mu'tazilah. Sedangkan fiqh terjebak dalam tradisi pemikiran "Al-Fuqaha AlSalafiyah". Hal tersebut telah menjadi ideologi yang membunuh pembahasan pembahasan yang bersifat ilmiah. Kajiannya selama sepuluh tahun inilah yang kemudian membawanya pada sebuah pemikiran bahwa sebenarnya Islam tidaklah seperti yang ada dalam kajian awal, yang hanya bersifat taqlidy dan terjebak dalam tradisi pemikiran pendahulunya. Hal ini tidak lain karena sesungguhnya kita tidak dapat menghadapkan produk pemikiran masa lalu ke masa kini dengan segenap problematikanya. Oleh karena itu, ia menegaskan perlunya umat Islam membebaskan diri dari bingkai pemikiran yang cenderung taqlidy (Syahrur, 1990:46).

Kedua, tahun 1980-1986. Fase ini diawali sejak pertemuan Syahrur dengan Ja'far Dak Al-Bab, teman sejawatnya mengajar di Universitas Damaskus yang lulus doktoralnya dalam bidang ilmu bahasa (al-Lisaniyyat) tahun 1973 di University Moskow. Ja'far inilah yang mengenalkannya dengan pemikiran-pemikiran Al-Faraby, Abu Ali Al-Farisy dan muridnya, Ibnu Jinny, dan Abdul Qohar Al-Jurjany. Berasal dari pemikiran mereka itulah, akhirnya ia memahami berbagai permasalahan bahasa seperti bahwasanya lafal itu mengikuti makna, 
bahasa Arab adalah bahasa yang tidak mengenal sinonim (muradhif). Bertolak dari sinilah kemudian ia mengadakan kajian yang intensif terhadap mushaf, baik yang itu berkenaan dengan istilah pokokdalam Al-Qur'an seperti: Al-Kitab, Al-Qur'an, Al-Furqan, Al-Dikr, Ummul Kitab, Al-Lauh Al-Mahfudz, Al-Imam Al-Mubin. Di samping tema-tema lain yang ia kaji dalam perspektif baru seperti: Al-Inzaal wa Al-Tanziil dan Al-Ja'1. Kajian ini berlangsung hingga tahun 1984-1986, ia mengkaji pemikiran-pemikiran pokok yang terkait dengan ayat-ayat Al-Qur'an bersama Ja'far Dak Al-Bab (Syahrur, 1990:47).

Ketiga, 1986-1990. Ini adalah fase upaya sistematisasi dari berbagai pemikirannya bersama Ja'far dalam sebuah buku yang kemudian diterbitkannya pada tahun 1990. Pekerjaan ini adalah sesuatu yang berat karena mereka harus memilah bagian demi bagian. Dia mengatakan bahwa untuk bab satu saja -dalam bukunya yang sudah jadi ini mencakup 200-an halaman- baru selesai selama setahun yakni 1986-1987. Buku yang mereka luncurkan ini baru secara total selesai tahun 1986 dengan jumlah halaman yang tidak main-main 800-an halaman.

Pemikiran Muhammad Syahrur dalam kajian keislamannya telah menimbulkan reaksi baik secara positif maupun sebaliknya. Hal ini disebabkan karena temuan-temuan barunya yang dinilai sangat kontroversial. Respon positif misalnya ditunjukkan oleh Sultan Qaboos yang membagi-bagikan buku tersebut dan merekomendasikan kepada menteri-menterinya untuk membacanya. Respon positif juga muncul di kalangan sarjana Barat yang banyak mengulas dan memberikan apresiasi terhadap pemikiran Syahrur. Ulasan tentang pemikirannya muncul di berbagai jurnal internasional seperti Jurnal Mide East Studies Assosiation (MESA), Jurnal Meria, The Wilson Quarterly, dan Muslim World, Islam and Cristian-Muslim Relations (Eickelman, 1988)

Di samping itu, respon negative juga muncul terhadap pemikiran Syahrur. Respon semacam ini nampaknya tidak kalah dahsyatnya. Banyak pemikir muslim yang tidak sependapat dengan pemikiran Syahrur memberikan responnya dengan menulis buku yang 
mengkritik Syahrur. Di antaranya, Tahafut Al-Qira'ah Al-Mu'ashirah karya Muhammad Syahrur karya Dr. Mahami Munir Muhammad Thahir Al-Syawwat dan Mujarrad Tanjim karya Salim Al-Jabiy.

Karya Syahrur yang telah menyedot banyak perhatian kalangan intelektual tersebut, beberapa tahun berikutnya disusul dengan karyakarya terbarunya, yaitu: Dirasah Islamiyyah fii Al-DAwlah wa Al-Mujtama' (1994), Al-Islam wa Al-Iman: Manzumah Al-Qiyam (1996), Masyru' Al'Amal Al-Islam (1999), dan semuanya diterbitkan oleh Al-Ahaliy lii AlTiba'ah wa Al-Nasys wa Al-Tawzi' di Damaskus. Walaupun buku-buku terbarunya tersebut getarannya tidak seperti buku pertama, namun bisa dikatakan bahwa buku-bukunya itu mampu memberikan perspektif baru dalam wacana pemikiran Islam kontemporer karena memang buku-buku itu menggambarkan proyek pemikiran keislamannya. Karya Syahrur tersebut dapat dikatakan pula sebagai titik balik (turning point) dalam karir intelektualnya dari seorang ilmuwan murni menjadi seorang pemikir keagamaan kontemporer. Syahrur adalah juga seorang penulis dalam bidang tehnik di antaranya ia telah mengarang buku Handasah Al-Asasat (ilmu fondasi) sebanyak empat jilid dan Handasah AlTurab (ilmu tanah).

\section{Pemikiran Kebahasaan}

Penulis melihat bahwasa fenomena seputar kontroversi Syahrur, mungkin juga pemikir kontemporer lainnya, telah menunjukkan betapa nalar teologis telah begitu berpengaruh di bawah sadar masyarakat Islam. Hal ini tidak lain, kita melihat bahwa reaksi terhadap pemikiran Syahrur adalah bersifat superficial dalam arti bahwa reaksi tersebut lebih mengacu pada produk pemikirannya dan belum melihat secara lebih substantive-filosofis. Dengan kata lain, apa landasan filosofis sehingga sebuah produk pemikiran itu muncul belumlah menjadi perhatian atau jarang dikenali oleh orang lain.

Penulis melihat bahwa pemikiran Syahrur yang kontroversial terkait erat dengan pendangannya secara filosofis tentang filsafat bahasa (asrar al-lisan al-'arabiy) yang kemudian berpengaruh pada pemikiran 
metodologis dan tentu saja pada titik akhirnya berpengaruh pula kepada produk pemikirannya.

Syahrur melihat bahwasanya dalam wilayah bahasa Arab terdapat perbedaan pandangan perihal dari manakah suatu kata berasal (musytaq)? Terdapat dua pandangan. Pertama, ulama Bashrah mengatakan bahwa kata itu musytaq dari bentuk mashdar, karena bentuk mashdar meruapakan kata yang belum mendapat tambahan, murni dan tersusun dari kata yang sedikit serta tidak berdimensi waktu. Kedua, ulama Kufah mengatakan, fi'il madhi-lah yang menjadi musytaq sebuah kata, sedang lain adalah cabang. Karena berawal dari fi'il madhilah perubahan-perubahan kata itu terjadi di samping fi'il madhi menunjukkan kepada waktu yang dahulu dan menunjukkan kepada sesuatu yang tidak tampak (ghaib).

Bertolak dari pemahaman ini, Syahrur kemudian memulai analisisnya terkait dengan kajian Al-Qur'an. Syahrur berpendapat bahwasanya dalam konteks kehidupan modern adalah tidak relevan lagi bagi umat Islam dalam memahami Al-Qur'an dengan pandangan ulama terdahulu. Syahrur dalm hal ini berpendapat bahwa secara substantive-filosofis pandangan ulama tersebut telah meniscayakan umat Islam senantiasa bersikap kembali ke masa lalu, mengandalkan kepada "sesuatu" yang gaib, sudah lewat. Hal inilah yang dalam perspektifnya menjadikan umat Islam bertindak di luar atau terpisah konteks waktu yang melingkupinya.

Pandangan inilah yang lalu memberikan "ilham" bagi Syahrur memberikan arah baru dalam kajian Al-Qur'an. Konstruksi filosofis Syahrur didasarkan pada pemikiran-pemikiran kebahasaan Ibnu Faris di samping juga dipertajam dengan analisis para pemikir (post) strukturalis Barat seperti Saussure, Levi-Strauss dan Jacobson.

Terdapat dua hal mendasar yang perlu dikedepankan terkait dengan pemikiran Syahrur. Pertama, penolakannya terhadap adanya sinonim (muradhif). Penolakan ini didasarkan pada pemikirab bahwa sesungguhnya kata dalam bahasa Arab mengandung perkembangan sejarah yang kadang-kadang hilang atau bahkan muncul makna baru 
yang disandarkan pada makna pertama. Hal inilah yang menjadikan sebuah kata mempunyai banyak arti (musytarak). Di samping itu, Syahrur berpendapat bahwa sinonim dalam konteks kata, pada hakikatnya adalah kembali ke masa lalu (marhalah tarikhiyyah qadimah). Hal ini kemungkinan yang mendorongnya untuk menolak muradif karena secara filosofis, mengakui adanya sinonim, berarti mengunggulkan sikap romantisme dengan masa lalu sehingga menghilangkan elan progresifisme dalam berpikir.

Kedua, Syahrur mengatakan bahwa yang menjadi musytaq dalam bahasa Arab adalah fi'il amr. Ia berpendapat bahwa dalam konteks waktu, sesuatu yang asal adalah bentuk bahasa manusia yang pertama. Bentuk bahasa pertama ini akan meniscayakannya mencari sesuatu yang lain dan itu tidak lain adalah "fi'il amr". Hal inilah yang secara filosofis menguntungkan adalah merupakan "bentuk perintah untuk menghadapi". Bentuk ini menggambarkan akan kecintaan manusia untuk bekerjasama di antara manusia, atau dengan kata lain fi'il amr menunjukkan etos progresifisme (Syahrur, 1990:818).

Dua hal inilah yang kemudian secar nyata berpengaruh terhadap konstruksi metodologisnya dalam mengkaji Al-Qur'an. Wajar jika kemudian produk-produk pemikirannya yang bersifat "nakal", memunculkan hal-hal baru yang banyak berbeda dengan pemikiran masyarakat umum. Pengetahuan terhadap landasan filosofis Syahrur, setidaknya akan menjadikan seseorang berfikir lebih jernih dan arif dalam memberikan penilaian terhadap sebuah karya pemikiran seseorang.

\section{Bahasa dan Realitas Sosial}

Kalau kita mencermati apa yang digagas oleh Syahrur, tampak dengan jelas bahwa pemikirannya tidak dapat dilepaskan dari situasi dan kondisi yang melingkupi masyarakat Islam saat ini. Sebagaimana kita dapat mencermati dengan jelas bahwa masyarakat muslim saat ini tengah dilanda oleh suatu kondisi yang sangat memprihatinkan. Masyarakat muslim yang selama ini memiliki jargon "Al-Islam ya'lu wa 
la yu'la 'alaih" telah menjadi masyarakat yang terpinggirkan dalam berbagai aspeknya (Syahrur, 1990:816).

Kondisi riil yang sedang dialami masyarakat muslim ini yang pada kenyataannya telah berperan di dalam memberikan "insight" dalam diri Syahrur. Bagi Syahrur, adalah sesuatu yang tepat jika dikatakan bahwa musytaq sebuah kata berasal dari fi'il madhi maupun isim mashdar. Fi'il Madhi, sebagaimana telah disinggung di atas, telah memberikan satu pencerminan sosial dan ini berwujud dalam ketidaksadaran (unconsciousness) masyarakat yang suka kembali pada masa lalu. Romatisme masa lalu untuk mengatasi keterpurukan muslim saat ini. Gagasan-gagasan kaum fundamentalis yang senantiasa ingin mewujudkan impian hadirnya khilafah Islam di masa kini adalah salah satu bentuk romantisme itu. Kita memang tidak bisa menyalahkan bentuk pemikiran romantisme seperti yang dilakukan oleh kaum fundamentalis tersebut. Tetapi, yang menjadi persoalan adalah apakah mungkin hanya dengan mengandalkan semangat romantisme itu Islam akan kembali jaya.

Dalam perspektif Syahrur, musytaq yang diambil dari fi'il madhi juga memberikan pemaknaan akan lemahnya elan progresifitas. Sama halnya dengan musytaq itu jika berasal dari isim atau kata benda yang bersifat pasif. Itulah sebabnya dalam pemikirannya, mustaq yang tepat dalam konteks sekarang adalah fi'il amr. Dengan itu dimaksudkan bahwa sikap yang inheren dalam diri setiap muslim sehingga pada akhirnya mampu menjadi ketidaksadaran kolektif. Elan progresif dan dinamis yang menjadi ketidaksadaran ini diharapkan akan mampu menjadikan umat Islam dapat menumbuhkan semangat dan ghirah mereka dalam mengejar ketertinggalan mereka dalam konstalasi global sekarang.

Kalau kita sependapat dengan apa yang dipaparkan oleh Chaika bahwa language as social mirror, tidak berlebihan juga jika dikatakan bahwa falsafah kebahasaan juga akan menjadi cermin bagi sebuah masyarakat. kita menyadari bahwa bahasa tidak dapat dilepaskan dari 
realitas sosial dan budaya, tempat bahasa itu digunakan sekelompok orang.

\section{Penutup}

Bahasa memang tidak dapat dipisahkan dari realitas sosial. Bahasa mempengaruhi sosial dan begitupun sebaliknya, sosial mempengaruhi bahasa. Bahasa di sini tentunya bukan dalam pengertian yang sangat sempit. Ia bisa mencakup banyak aspek termasuk filsafat bahasa. Pemikiran Syahrur yang mencoba memberikan pemikiran baru tentang asal kata (musytaq) dapat dikatakan sebagai salah satu bukti yang memperkuat pernyataan di atas.

Pemikiran bahwa musytaq kata dalam bahasa Arab adalah fi'il amr tidak dapat dari refleksi filosofis Syahrur dalam melihat realitas sosial umat Islam yang terpuruk, menyenangi pada hal-hal masa lampau (madhi) atau romantisme serta elan progresifnya yang lemah (pasif). Melalui refleksi tersebut diharapkan akan menjadi satu kesadaran bahwa yang diperlukan pada saat ini adalah fi'il amr (aktif) dan untuk kemudian hal itu akan menjadi ketidaksadaran karena sudah menginternal dalam pribadi muslim yang cinta akan kemajuan. $\square$

\section{DAFTAR PUSTAKA}

Al-Jabiy, Salaim. 1991. Mujarrad Tanjim. Damaskus: AKAD.

Al-Syawwaf, Mahammi Munir Muhammad Thahir. 1993. Tahafut AlQira'ah Al-Mu'ashirah. Cyprus: Al-Nasyr.

Eickelman, Dale F.. 1988. "Inside The Islamic Reformation", dalam The Wilson Quarterly 22, Nomor 1. 1993. "Islamic Liberalism Strike Back", dalam MESA Bulletin 27, 1 Desember. 
Kurzman, Charles (Ed.). 1998. Liberal Islam, A Sourcebook. New YorkOxford: Oxford University Press.

Maftuh, Agus, ett.all. 2004. Negara Tuhan. Yogyakarta: SR-Ins Publishing.

Nasution, Harun. 1975. Pembaharuan dalam Islam: Sejarah dan Gerakan. Jakarta: Bulan Bintang.

Rahardjo, Mudjia. 2002. Relung-relung Bahasa.Yogyakarta: Aditya.

Syahrur, Muhammad. 1990. Al-Kitab wa Al-Qur'an: Qira'ah Mua'shirah. Damaskus: Al-Ahaly Al-Thiba'ah wa Al-Nasyr Al-Tauzi'. 